\title{
Internalisasi Karakter Konservasi Lingkungan melalui Media Game Deservasi
}

\author{
Fajar Arif Setyawan ${ }^{1}$, Asmida Ulfa Laelasari ${ }^{2}$ \\ ${ }^{1,2}$ Jurusan Ilmu Komputer, FMIPA, Universitas Negeri Semarang \\ Email: ${ }^{1}$ fajarmath@gmail.com
}

\begin{abstract}
Abstrak
Kepedulian terhadap lingkungan harus dimiliki oleh setiap manusia. Sikap peduli terhadap lingkungan dapat diwujudkan di antaranya dengan kebiasaan membuang sampah pada tempatnya, melestarikan lingkungan alam yang asri dan pemanfaatan sumber daya alam secara bijaksana. Munculnya berbagai permasalahan lingkungan yang disebabkan oleh kelalaian manusia perlu diatasi dan diantisipasi dengan penanaman nilai-nilai kepedulian terhadap lingkungan, bahkan perlu ditanamkan kepada setiap manusia sejak masa anak-anak. Media penanaman nilai-nilai kepedulian terhadap lingkungan kepada anak-anak perlu disesuaikan dengan ketertarikan mereka. Media game Deservasi yang dikembangkan dengan menggunakan Unity 3D akan menjadi media penanaman nilainilai kepedulian lingkungan yang efektif dan menyenangkan bagi anak-anak. Jenis genre game Deservasi adalah jenis permainan arcade game.
\end{abstract}

Kata kunci: Konservasi lingkungan, Game Deservasi, Unity $3 D$.

\section{PENDAHULUAN}

Perkembangan teknologi terjadi sangat pesat di era globalisasi. Hal ini salah satunya ditunjukkan dengan adanya perangkat keras dan lunak yang sangat pesat perkembangannya dalam kehidupan sehari-hari. Dengan berkembangnya teknologi, maka banyak bermunculan gadget yang mempunyai fitur-fitur canggih dan dalam gadget tersebut terdapat pula permainan-permainan yang berkonsep modern, baik permainan yang ber-platform untuk desktop atau mobile. Permainan-permainan ini semakin berkembang seiring perkembangan zaman. Dengan banyaknya permainan modern yang muncul, lain halnya dengan permainan-permainan yang mempunyai nilai pendidikan yang mulai ditinggalkan. Salah satu nilai pendidikan yang dapat diterapkan dalam game berbasis mobile adalah nilai konservasi lingkungan. Lingkungan merupakan segala sesuatu yang ada di sekitar manusia yang mempengaruhi kehidupan manusia baik secara langsung maupun tidak langsung. Persoalan lingkungan telah lama menjadi topik dunia ketika manusia mulai merasakan dampaknya yang semakin meluas yakni terlihat pada banyaknya bencana. Namun, hingga kini masalah ini masih menjadi mimpi buruk dan menjadi tugas besar untuk diselesaikan bersama. Salah satu masalah lingkungan yang sangat penting dan mendapat perhatian serius saat ini adalah sampah.

Berdasarkan permasalahan tersebut maka muncul gagasan untuk membuat game yang mengandung nilai pendidikan. Nilai pendidikan yang diterapkan pada game merupakan nilai-nilai konservasi lingkungan yang mengadopsi keadaan lingkungan sekitar yang mencerminkan konservasi. Menggunakan konsep modern yang memanfaatkan platform mobile berbasis android. Selanjutnya game yang akan dikembangkan disebut game Deservasi. 


\section{METODE}

\subsection{Rancangan Game}

Jenis genre game deservasi adalah jenis permainan arcade game. Dalam game ini ada karakter utama yang bernama Cody dan beberapa karakter lainya yaitu musuh yang harus ditaklukan dalam game ini. Untuk mengalahkan musuh, si Cody harus dapat memilih sampah-sampah yang berserakan disekitarnya. Pemilihan sampah-sampah yang berserakan berdasarkan dari sampah organik dan anorganik secara benar dan teratur. Tetapi saat pengambilan sampah, si Cody juga menemukan beberapa musuh yang mencoba menyerangnya untuk menggagalkannya menyelesaikan misi konservasi lingkungan.

Pada game deservasi, terdapat beberapa cara untuk mendapatkan skor yaitu dengan melewati musuh-musuh yang mencoba untuk mengagalkan misi Cody. Setelah bisa melewatinya, Cody akan mendapatkan skor 5 dan saat bisa memilih sampah-sampah tersebut, Cody akan mendapatkan skor 10. Stage finish score akan menampilkan akumulasi jumlah health yang tersisa dan akan tercatat di bagian "highscore".

\subsection{Rancangan Grafis}

\subsubsection{Tampilan gambar}

Dalam game Deservasi terdapat beberapa tampilan gambar, yaitu:

a. Menu utama.

Pada tampilan ini, pemain akan memilih tombol play, menu pengaturan, petunjuk atau keluar dari permainan.

b. Menu pengaturan.

Pada tampilan ini, pemain dapat mengatur aktif tidaknya musik dan soundFx.

c. Tampilan permainan.

Tampilan ini merupakan tampilan utama di mana pemain dapat memulai permainan game Deservasi.

d. Tampilan game over.

Tampilan game over merupakan tampilan ketika pemain tidak dapat menyelesaikan permainan atau kalah dalam permainan. Pada tampilan ini, juga akan muncul pilihan menu untuk pemain, yaitu ingin mengulang permainan atau keluar dari permainan.

e. Tampilan pause.

Tampilan ini menghentikan permainan secara sementara dan akan memberikan pilihan tombol resume (kembali ke permainan), restart (mengulangi permainan dari awal), menu (kembali ke menu awal), setting (menuju ke menu pengaturan) dan exit (keluar dari permainan).

\subsubsection{Rancangan Menu Utama}

Tampilan awal dari game adalah tampilan dengan menu utama yang berisi gambar background, play, help, setting, missions, character, shop dan highscore seperti pada Gambar 1. 


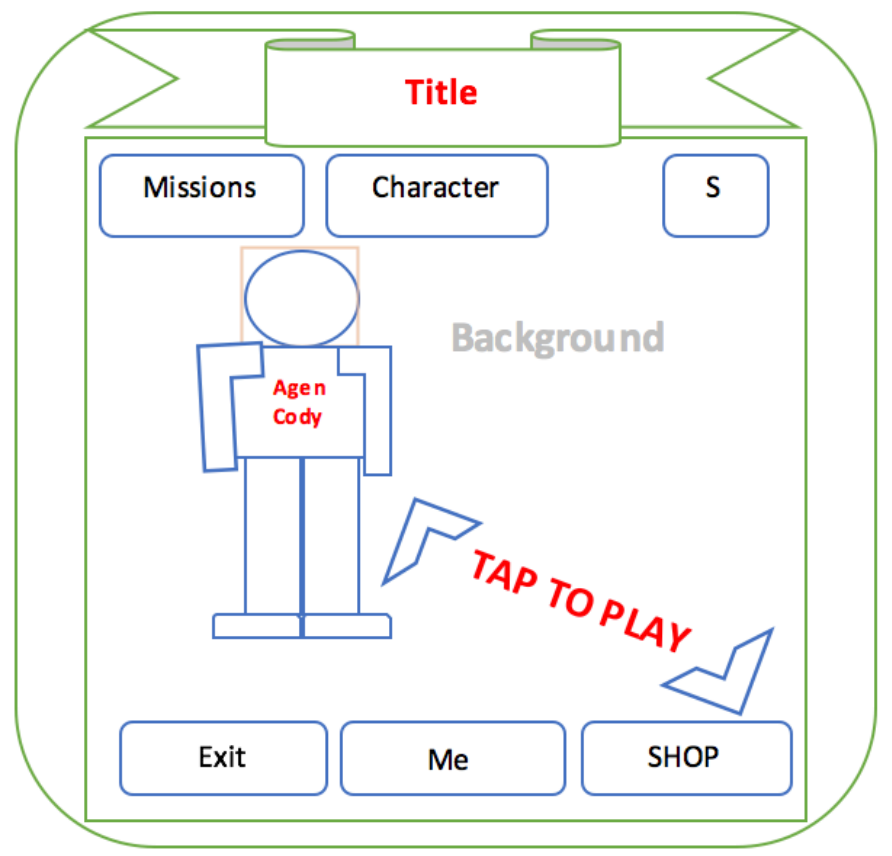

Gambar 1. Rancangan Main Menu

Keterangan:

a. Title adalah tempat judul game yang akan ditempatkan.

b. Missions adalah tempat untuk meletakkan tombol missions yang berfungsi untuk mengetahui misi apa saja yang akan dikerjakan.

c. Character adalah tempat untuk meletakkan tombol character yang berfungsi untuk mengetahui character apa saja yang dapat dipakai untuk menjalankan misi.

d. S adalah tempat untuk meletakkan tombol yang berfungsi untuk melihat menu game setting seperti mengatur suara dan musik.

e. Background adalah gambar yang menjadi latar belakang menu.

f. Tap To Play adalah tempat untuk meletakkan tombol yang berfungsi untuk memulai permainan.

g. Exit adalah tempat untuk meletakkan tombol yang berfungsi untuk keluar dari permainan.

h. Me adalah tempat untuk meletakkan tombol about yang berfungsi untuk melihat pembuat game.

i. Shop adalah tempat untuk meletakkan tombol shop yang berfungsi untuk membeli accesories yang dapat digunakan oleh character seperti baju, topi, dan lain-lain.

\subsubsection{Rancangan Menu Missions}

Pada menu missions terdapat tombol back home untuk kembali pada menu home dan terdapat beberapa missions yang harus diselesaikan, di samping menu mission terdapat 
tombol S yang gunanya untuk mengetahui score yang diperoleh pada masing-masing misi. Rancangan menu missions ditunjukkan pada Gambar 2.

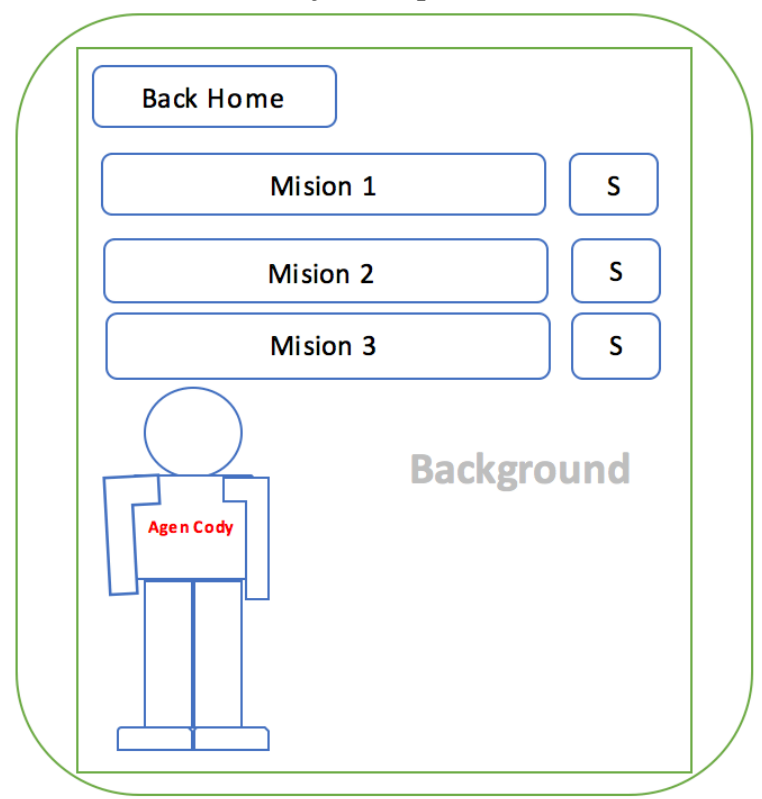

Gambar 2. Rancangan menu missions

\subsubsection{Rancangan Menu Character}

Pada rancangan menu character terdapat beberapa pilihan character yang dapat digunakan dengan memilih tombol next atau prev setelah yakin akan menggunakan character tersebut, klik tombol selected yang dapat dilihat pada Gambar 3.

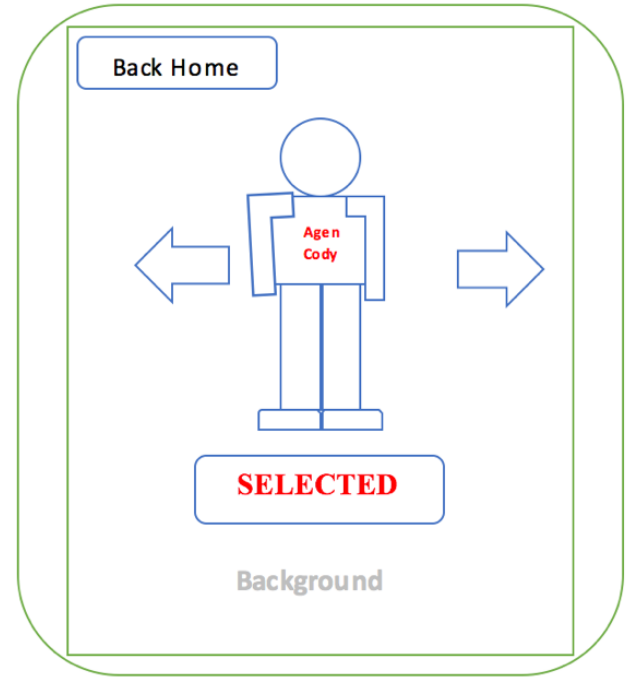

Gambar 3. Rancangan menu character 


\subsubsection{Rancangan Menu Setting}

Tampilan setting adalah tampilan yang menampilkan pilihan untuk mengatur musik atau soundFx permainan. Rancangan tampilannya adalah pada Gambar 4.

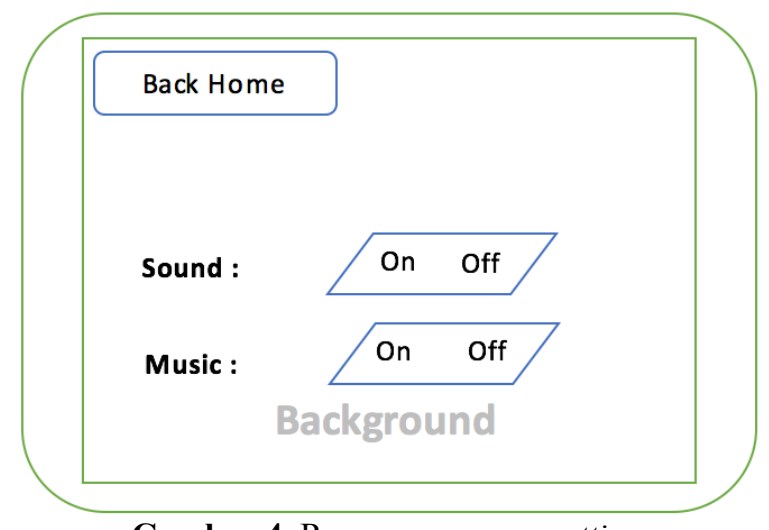

Gambar 4. Rancangan menu setting

\section{HASIL DAN PEMBAHASAN}

Secara umum, konservasi mempunyai arti pelestarian yaitu melestarikan atau mengawetkan daya dukung, mutu, fungsi, dan kemampuan lingkungan secara seimbang [1]. Tujuan konservasi adalah sebagai berikut:

a. Mewujudkan kelestarian sumber daya alam hayati serta keseimbangan ekosistemnya, sehingga dapat lebih mendukung upaya peningkatan kesejahteraan dan mutu kehidupan manusia.

b. Melestarikan kemampuan dan pemanfaatan sumberdaya alam hayati dan ekosistemnya secara serasi dan seimbang. Selain itu, konservasi merupakan salah satu upaya untuk mempertahankan kelestarian satwa. Tanpa konservasi akan menyebabkan rusaknya habitat alami satwa. Rusaknya habitat alami ini telah menyebabkan konflik manusia dan satwa.

Konservasi lahir akibat adanya kebutuhan untuk melestarikan sumber daya alam yang diketahui mengalami degradasi mutu. Dampak degradasi tersebut menimbulkan kekhawatiran dan akan membahayakan umat manusia, terutama berimbas pada kehidupan generasi mendatang [2]. Batasan konservasi dapat dilihat berdasarkan pendekatan tahapan wilayah yang dicirikan oleh:

a. Pergerakan konservasi, ide-ide yang berkembang pada akhir abad ke-19, yaitu yang hanya menekankan keaslian bahan dan nilai dokumentasi.

b. Teori konservasi modern, didasarkan pada penilaian kritis pada bangunan bersejarah yang berhubungan dengan keaslian, keindahan, sejarah, dan penggunaan nilai-nilai lainnya [3].

Sementara itu, Piagam Burra menyatakan bahwa pengertian konservasi dapat meliputi seluruh kegiatan pemeliharaan dan sesuai dengan situasi dan kondisi setempat. Oleh karena itu, kegiatan konservasi dapat pula mencakupi ruang lingkup preservasi, 
restorasi, rekonstruksi, adaptasi dan revitalisasi [4].

Hal tersebut bertujuan untuk tetap memelihara identitas dan sumber daya lingkungan dan mengembangkan beberapa aspeknya untuk memenuhi kebutuhan arus modernitas dan kualitas hidup yang lebih baik. Dengan demikian, konservasi merupakan upaya mengelola perubahan menuju pelestarian nilai dan warisan budaya yang lebih baik dan berkesinambungan. Dengan kata lain bahwa dalam konsep konservasi terdapat alur memperbaharui kembali (renew), memanfaatkan kembali (reuse), mengurangi (reduce), mendaur ulang kembali (recycle), dan menguangkan kembali (refund).

Dalam [5] disimpulkan bahwa model bimbingan untuk mengembangkan karakter anak usia dini melalui permainan terbukti efektif mengembangkan hampir semua indikator karakter anak usia dini dan meningkat secara signifikan setelah menggunakan pendekatan bimbingan melalui permainan. Hal tersebut salah satunya dipengaruhi oleh fakta bahwa permainan adalah kegiatan yang menyenangkan bagi anak-anak. Jadi, permainan dapat dijadikan sebagai media intervensi karakter baik untuk anak usia dini.

Konservasi terhadap lingkungan alam memiliki arti yaitu melestarikan lingkungan alam. Perilaku manusia terhadap lingkungan dipengaruhi oleh kepedulian mereka terhadap kelestarian alam sekitar. Banyaknya perilaku manusia yang dapat merusak alam dapat diperbaiki dengan penanaman nilai-nilai kepedulian terhadap lingkungan. Nilai-nilai tersebut perlu ditanamkan kepada manusia sejak masih anak-anak. Media game deservasi yang rancangannya telah dibahas pada bagian sebelumnya merupakan media yang efektif dalam usaha menanamkan nilai-nilai konservasi lingkungan. Anakanak yang terbiasa bermain game tersebut akan terbiasa pula dalam melakukan usaha menjaga kelestarian alam. Hal sederhana yang dapat ditanamkan adalah mereka akan terbiasa dalam memilah jenis sampah, kemudian memasukkan sampah ke dalam tempat yang sesuai dengan jenisnya. Semakin meningkatnya level permainan, maka semakin kuat pula musuh yang harus dihadapi sehingga anak-anak harus lebih jeli dalam memikirkan strategi demi mengalahkan musuh dan menjaga kelestarian lingkungan alam yang ada dalam game.

Pengembangan game Deservasi dengan menggunakan Unity 3D dapat dilakukan secara mudah dan cepat. Unity dapat mendukung pembuatan game dalam berbagai platform, misalnya Unity Web, Windows, Mac, Android, iOS, XBox, Playstation 3 dan Wii [6]. Pada Unity terdapat beberapa hal penting dalam membuat atau membangun suatu karya, diantaranya yaitu:

\section{a. Project.}

Project merupakan kumpulan dari komponen-komponen yang dikemas menjadi satu dalam sebuah software agar bisa dikembangkan menjadi sebuah aplikasi. Pada Unity, project berisi identitas aplikasi yang meliputi nama project, platform building. Kemudian package apa saja yang akan digunakan, satu atau beberapa scene aplikasi, asset, dan lain-lain.

b. Scene.

Scene dapat disebut juga dengan layar atau tempat untuk membuat layar aplikasi. Scene 
dapat dianalogikan sebagai level permainan, meskipun tidak selamanya scene adalah level permainan. Misal, level 1 diletakkan pada scene 1 , level 2 pada scene 2, dan seterusnya. Namun scene tidak selamanya berupa level, bisa jadi lebih dari satu level diletakkan dalam satu scene. Game menu biasanya juga diletakkan pada satu scene tersendiri. Suatu scene dapat berisi beberapa game object. Antara satu scene dengan scene lainnya bisa memiliki game object yang berbeda.

c. Asset dan package.

Asset dan package adalah mirip, suatu asset dapat terdiri dari beberapa package. Asset atau package adalah sekumpulan object yang disimpan. Object dapat berupa game object, terrain, dan lain sebagainya.

\section{SIMPULAN}

Desain yang menarik dan menu-menu serta pengaturan yang mudah dipahami oleh anak-anak, menjadikan game Deservasi berpotensi dijadikan sebagai media penanaman nilai-nilai konservasi lingkungan. Anak-anak secara tidak langsung belajar untuk memahami bahwa menjaga kelestarian lingkungan alam adalah suatu hal yang penting. Mereka juga bisa mengambil ilmu yang bisa diterapkan dalam kehidupan sehari-hari. Ilmu mengenai konservasi lingkungan yang diinternalisasi secara terus menerus melalui game yang dimainkan akan tertanam dalam diri anak-anak. Pengembangan game Deservasi yang menggunakan Unity 3D merupakan suatu usaha yang mudah dilakukan sehingga dapat dikembangkan secara berkelanjutan.

\section{REFERENSI}

[1] MIPL. 2010. Konservasi. STMIK AMIKOM, Purwokerto.

[2] Rachman, M. 2012. Konservasi Nilai dan Warisan Budaya. Indonesian Journal of Conservation. Vol. 1(1): 30-39.

[3] Antariksa. 2009. Makna Budaya dalam Konservasi Bangunan dan Kawasan. http://antariksaarticle.blogspot.com diakses 26 Februari 2015.

[4] Marquis-Kyle, P. dan Walker, M. 1996. The Illustrated BURRA CHARTER. Making good decisions about the care of important places. ICOMOS, Australia.

[5] Kurnia, A. 2014. Model Bimbingan untuk Mengembangkan Karakter Anak Usia Dini melalui Permainan. Jurnal Penelitian Pendidikan. Vol. 14(2):139-145.

[6] Setya, I. 2010. Pemanfaatan Augmented Reality Untuk Pembelajaran Pengenalan Alat Musik Piano. Makalah Seminar Tugas Akhir. Prodi Sistem Komputer, Fakultas Teknik, Universitas Diponegoro. 
90 | Scientific Journal of Informatics, Vol. 2, No. 1, Mei 2015 